\title{
Challenges in Emergency Remote Teaching Among Malaysian Public Elementary School Teachers
}

\author{
https://doi.org/10.3991/ijet.v16i24.27453 \\ Yong Keow Lee ${ }^{1}$, Norasykin Mohd Zaid ${ }^{2}(\varpi)$, Nur Husna Abd. Wahid ${ }^{2}$, \\ Zakiah Mohamad Ashari², Nornazira Suhairom², \\ Mohd Nihra Haruzuan Mohamad Said ${ }^{2}$ \\ ${ }^{1}$ Rocz Child Care Center, Johor, Malaysia \\ ${ }^{2}$ Universiti Teknologi Malaysia, Johor, Malaysia \\ norasykin@utm.my
}

\begin{abstract}
The purpose of this study was to explore challenges public elementary school teachers faced when conducting emergency remote teaching during pandemic in Malaysia. The scope of the study was limited to remote teaching which was conducted between Mar 2020 and December 2020, when Malaysia government urged an emergency national lockdown to stop the spread of coronavirus in the country. This study adopted qualitative, case study research design. Ten public elementary school teachers were sampled using a purposive sampling method. Semi-structured interviews were employed to gain the insights of teachers' challenges in implementation of emergency remote teaching. The data were analysed using thematic analysis and a facilitation of Nvivo 12 programme. There were six main themes emerged on teachers' challenges, which were (1) Directing gateway; (2) Lack of skill and knowledge; (3) Unable to meet all needs; (4) Unable to engage students; (5) Lack of support from parents; and (6) Had no proper guideline. As teachers were the key persons in determining the functionality, effectiveness and development of future remote teaching, hence it was extremely crucial to listen to teachers' voices and figure out how these educators could be supported in the future to benefit the learners and communities.
\end{abstract}

Keywords-emergency remote teaching, challenges, education, covid-19, elementary school teacher

\section{Introduction}

In March and November, 2020, Malaysia government urged an emergency lockdown in the country to stop the spread of coronavirus. During the lockdown period, all schools and education institutions were closed, all the students and educators had to stay home and get on an emergency remote teaching and learning that they had never experienced before [1]. Suspending offline teaching at school and turning to online education [2] or suspending classes without stopping learning [2] policy was embraced to ensure the continuity of education. Students and educators from national public schools under the Ministry of Education were entitled to a registered Google email account and 
Paper-Challenges in Emergency Remote Teaching Among Malaysian Public Elementary School...

free access to all Google applications to continue teaching and learning activities. Teachers were encouraged to use Google Classroom as a platform to share instructional contents as well as materials, and Google Meet was utilized to be the video-conferencing tools to deliver instruction. As teachers had little or no training in conducting online teaching, the migration from face-to-face teaching systems into online systems that had never been implemented or trained before had led to tremendous problems.

Plenty of research addresses this sudden shift of education format as emergency remote teaching which means a temporary shift of instructional delivery to an alternate delivery mode due to crisis circumstances $[12,16]$. Educators believe that this migration is temporary and everything will go back to normal when the pandemic is over. Some research indicated that there was a significant change in teachers' perception regarding their resolutions to implement technology in their lessons in a post-corona era $[17,37]$. Educators also believed that with technology, students can actively learn and understand concepts meaningfully $[25,28,38,40]$. However, researchers would like to see this fly-by-night transformation as a catalyst to educational technology [13, 26, 29]. Although this implementation was addressed as an emergency, however, no one knew when this crisis would fade. It is possible that even with an effective vaccine, there will be a prolonged post-pandemic recovery of another two to three years. By exploring the challenges encountered by education front-liners, researchers could develop an appropriate teaching framework to ensure the continuity, integrity and quality of nation education.

\section{$2 \quad$ Literature review}

Emergency remote teaching (ERT) is a temporary shift of instructional delivery to an alternate delivery mode due to crisis circumstances [16]. This is an emergency response mechanism, a temporary method or an alternative way of teaching due to the pandemic [31]. The main objective of emergency remote teaching is not to re-create a robust educational ecosystem but rather to provide temporary access to instructional support which is more efficient, fast and reliable during an emergency or crisis [16]. This means once the epidemic is under control, students and teachers all over the world will return to their original schools and conduct educational activities in a precious way. In the eyes of most educators, this is only a short-lived coping mechanism.

\subsection{Difference between emergency remote learning and online learning}

Emergency remote learning is different from online learning. A research of [16] stated the difference between emergency remote teaching and online learning. The findings of the research were summarized in Table 1 as follow: 
Paper-Challenges in Emergency Remote Teaching Among Malaysian Public Elementary School...

Table 1. Difference between emergency remote learning and online learning [16]

\begin{tabular}{|l|c|c|}
\hline & Emergency remote Learning & Online learning \\
\hline Designed by & Anyone & Professional instructional technologist \\
\hline Development time & A single day to few weeks & Six to nine months \\
\hline Help desk assistance & No & Yes \\
\hline Resources & Self-supported & Supported by institution \\
\hline Cost of building & Quick and inexpensive & $\begin{array}{c}\text { Slow and need proper } \\
\text { planning and investment }\end{array}$ \\
\hline Interaction & $\begin{array}{c}\text { Student - content } \\
\text { Merely information transmission }\end{array}$ & $\begin{array}{c}\text { Student - content } \\
\text { Student - student } \\
\text { Social-cognitive process }\end{array}$ \\
\hline Pacing & Class-paced & $\begin{array}{c}\text { Self-paced (open entry, open exit) } \\
\text { Class-paced } \\
\text { Class-paced with some self-paced }\end{array}$ \\
\hline Student role & Listen, read, \\
& Complete problions and answer & $\begin{array}{c}\text { Listen, read, } \\
\text { Complete problems and answer question, } \\
\text { collaborate with peers, } \\
\text { Explore simulation and resources }\end{array}$ \\
\hline
\end{tabular}

\subsection{Difference between face-to-face teaching and online teaching}

On the other hand, saying that face-to-face teaching and online teaching is pedagogically different is certainly an understatement [39]. After synthesizing the various documents and resources, the researcher made the following summary regarding the difference between face-to-face teaching and online teaching. The obvious differences between face-to-face and online learning are the teacher's role and responsibilities to the learning process. Online learning is not only emphasizing the preprocess teaching preparation but also includes the ongoing process, and post process of teaching. The differences between face-to-face and online teaching were presented in Table 2.

Table 2. Difference between face-to-face teaching and online teaching $[5,7,8,26,33]$

\begin{tabular}{|c|c|}
\hline Face-to-face teaching & Online teaching \\
\hline $\begin{array}{l}\text { Teachers spend a lot of time prepare content and } \\
\text { delivering }\end{array}$ & $\begin{array}{l}\text { Teachers spend a lot of time guiding the students as } \\
\text { they interact with the context which was prepared by } \\
\text { the educator or from other sources }\end{array}$ \\
\hline $\begin{array}{l}\text { Teacher is the Sage on the stage, sole source of in- } \\
\text { formation [39] }\end{array}$ & $\begin{array}{l}\text { Teacher is the Facilitator or guide; } \\
\text { They are also online course designers, resource man- } \\
\text { agers and technology experts. [39] }\end{array}$ \\
\hline $\begin{array}{l}\text { Flexible to make changes immediately to the con- } \\
\text { tent and teaching time based on the situation [7] }\end{array}$ & $\begin{array}{l}\text { Have to carefully plan the content in advance before } \\
\text { students interact with the content. }\end{array}$ \\
\hline $\begin{array}{l}\text { Able to observe students' reaction or expression to } \\
\text { justify whether they understand the content [26] }\end{array}$ & $\begin{array}{l}\text { Only able to observe the situation through the online } \\
\text { activities, such as Q\&A, forums, discussion, etc. }\end{array}$ \\
\hline $\begin{array}{l}\text { Teacher requires real-life classroom management } \\
\text { skills }\end{array}$ & $\begin{array}{l}\text { Teachers control the environment in virtual class- } \\
\text { room }\end{array}$ \\
\hline In-person interaction during lecturing session & $\begin{array}{c}\text { Continue interact through emails, texting even after } \\
\text { office hour }\end{array}$ \\
\hline $\begin{array}{l}\text { Must be taught by teacher through in-person inter- } \\
\text { action }\end{array}$ & $\begin{array}{l}\text { Effective as online learning can be delivered in either } \\
\text { synchronous or asynchronous format }\end{array}$ \\
\hline
\end{tabular}


Paper-Challenges in Emergency Remote Teaching Among Malaysian Public Elementary School...

\subsection{Teachers' challenges}

Many researchers have studied teachers' experiences and challenges faced in emergency remote teaching. Teachers' challenges were identified in three major categories, including challenges related to instructors, learners and content development [14]. In most developing countries, the utmost challenge faced in remote teaching was poor infrastructure or inadequate internet connection service to access online teaching and learning $[1,2,11,12,18,20,24,29]$. Besides, some research indicated that teachers lack the knowledge and skills $[12,18,19,23,27,29]$ to conduct online teaching and learning activities as they did not have any experiences or training in online teaching. Some teachers encountered problems with conditioning students and collaboration with parents [11] and cybersecurity threats [29].

Many studies indicated that teachers' motivation in remote teaching during pandemic was affected by psychological and social factors instead of instructional obligation [3]. Teachers' motivation and satisfaction were influenced by the attitude and behaviour of stakeholders [36]. As teachers have to work hard to look for creative ways to engage students to promote students' enthusiasm for learning, this is the key factor which affects teachers' satisfaction [3]. A study conducted by [30] claimed that a low level of social interaction within the pandemic context can lead to teacher's burnout. Some teachers felt stressed and isolated, poor confidence in online platforms, perceived a higher workload as well as negative emotions in conducting emergency remote teaching due to shortcoming in training and technical barriers [21, 24, 31, 34].

Majority of teachers did not agree that the traditional approach of learning could be replaced by remote or online teaching [24]. Nevertheless, they agreed that remote teaching was a better alternative for learning during the pandemic period. Some teachers perceived that the online classes were more structured in approach, lesser disturbance and the online tools like video, charts, record functions made teaching more systematic [26].

\section{Methodology}

This study adopted a case study research method. A purposive sampling method was employed to sample 10 public elementary school teachers in Johor. The rationale of using purposive sampling was resulted from a content-analysis of literature while searching for the research gap. Most of the studies on ERT were focused on secondary school and college teachers' experiences in teaching Science and Mathematics subjects. Hence, the researchers aimed to focus on elementary school teachers who taught language subjects. The selection of respondents was based on the criteria of the study, where the participants had at least 5 years of teaching experience inn public elementary schools, had conducted emergency remote teaching during pandemic from March - December 2020, had taught language subjects like Bahasa Malaysia and English in emergency remote teaching, had good internet connection as the interview sessions were conducted online. Semi-structured interviews were conducted to explore the challenges faced by public elementary school teachers in emergency remote teaching. The instru- 
ment used in this study was self-developed. The development of the instrument included four phases, which were planning, construction, evaluation and validation [9]. A pilot test was conducted to increase the reliability of the instrument as well as for further refinement. The instrument was verified by five experts in the field of educational technology to ensure the validity, the appropriateness and preciseness of the terms used in the instruments.

In order to explore the insight of teachers' challenges in conducting ERT, in-person semi-structured interviews were conducted online using Google Meet application. The rationale of using the interview as a data collection method was to enable the researchers to find out what and how teachers did, what was in their mind and what kinds of challenges they faced in conducting emergency remote teaching. Using interview as a method could provide a clear and in-depth finding as well as more accurate data through personal interaction with the interviewees.

A consent letter was sent to all the respondent teachers before the interview session. The informed consent indicated that the participation is voluntary and respondents could withdraw any time without any outcome, their identities were confidential and anonymous. After signing the consent, each participant received an email as an invitation or reminder in their Google Calendar indicating that the appointment for interview has been confirmed.

In this study, all the interview sessions were conducted by researchers own-self. Each interview session took about 40-60 minutes. The interview was conducted in the language of each participants' preference, which was Malays or English. Before the interview, a few open-ended questions were prepared according to the objective of this study. During the interview sessions, the open-ended questions were accompanied by follow-up why and how questions to get the in-depth data on the agenda or topics. Prompts and probing were used to encourage and generate more response from the participants. The whole interview session has been recorded for revision.

After the data has been collected, all the recorded contents in interview sessions were written down, including hesitation and expressions. A close observation on verbal and non-verbal interaction was done by repeating listening and watching the recorded interview session. The transcript procedure was done by researchers own-self as well to serve as the first stage of familiarization of collected data. The transcripts were then altered for readability before sent back to respondents for checking. After that, the collected data were analysed using thematic analysis which included 6 phases, familiarization, coding, searching for themes, reviewing the themes, defining and naming themes. This process was facilitated by a Nvivo 12 programme.

\section{Data analysis}

In the data analysis process, the researchers adopted thematic analysis which is frequently employed in qualitative psychology study. The psychology qualitative researchers, Virginia Braun and Victoria Clarke mentioned in their study, "Analysis involves a constant moving back and forward between the entire data set, the coded extracts of data that you are analysing, and the analysis of the data that you are producing" 
[6]. In the phase of familiarization, researchers closely examined the data or the set of interview transcripts to identify common themes, including topics, ideas and patterns of meaning that appeared repeatedly. After familiarizing themselves with all the data, the researchers assigned as many as possible preliminary or initial codes to describe the content to avoid losing too much content. Then, the researchers searched for patterns in codes across different interviews. All the codes were written on sticky notes to allow researchers collage or move code back and forth to form broader themes while repeatedly reviewing all the data to make sure there was nothing missing. A map of codes and themes was drawn to help researchers to visualize the relationship of each code and theme. In the final stage of data analysis, all the themes were reviewed, refined and renamed. According to Braun and Clarke, the theme's name should be descriptive and engaging, where it defines the essence of each theme is about [6]. The final stage of data analysis has been done with the assistance of member check and has been verified by a group of experts to avoid bias.

There were six main themes emerged for teachers' challenges faced in emergency remote teaching during pandemic, namely (1) Directing gateway; (2) Lack of skill and knowledge; (3) Unable to meet all needs; (4) Unable to engage students; (5) Lack of support from parents; (6) had no proper guideline (See Table 3). Table 3 presented challenges, problems or barriers encountered by public elementary school teachers when conducting emergency remote teaching during pandemic.

Table 3. Coding phase and emerged themes for teachers' challenges

\begin{tabular}{|c|c|c|}
\hline Phases in teaching & Main themes & Codes \\
\hline $\begin{array}{l}\text { Planning } \\
\text { Instruction }\end{array}$ & Directing gateway & $\begin{array}{l}\text { Learn how to use online platform } \\
\text { Deal with technical problems } \\
\text { Deal with different parents } \\
\text { Assist students and parents to access platform }\end{array}$ \\
\hline $\begin{array}{l}\text { Developing } \\
\text { instruction } \\
\text { materials }\end{array}$ & $\begin{array}{l}\text { Lack of knowledge } \\
\text { and skill }\end{array}$ & $\begin{array}{c}\text { Convert paper-based materials to digital-based } \\
\text { Learn to create presentation slides } \\
\text { Learn to use google form } \\
\text { Learn to create and record videos } \\
\end{array}$ \\
\hline \multirow[t]{3}{*}{$\begin{array}{l}\text { Delivering } \\
\text { instruction }\end{array}$} & $\begin{array}{l}\text { Unable to meet stu- } \\
\text { dents' need }\end{array}$ & $\begin{array}{l}\text { Can't provide immediate feedback } \\
\text { Can't provide extra support }\end{array}$ \\
\hline & $\begin{array}{l}\text { Unable to } \\
\text { engage students }\end{array}$ & $\begin{array}{c}\text { Students disappeared and absent } \\
\text { Students switched off mic and camera } \\
\text { Students didn't respond to question } \\
\text { Teacher talked alone } \\
\text { Students were doing other things at the same time }\end{array}$ \\
\hline & $\begin{array}{l}\text { Lack of support from } \\
\text { parents }\end{array}$ & $\begin{array}{c}\text { Parents watched them teaching and criticised } \\
\text { Parents caused disturbance } \\
\text { Parents said teacher was lazy } \\
\text { Parents didn't respond to messages }\end{array}$ \\
\hline $\begin{array}{l}\text { Evaluate students' } \\
\text { performance }\end{array}$ & $\begin{array}{l}\text { Had no proper guide- } \\
\text { line }\end{array}$ & $\begin{array}{c}\text { Based on attendance }- \text { not fair } \\
\text { Based on homework }- \text { not reliable } \\
\text { Based on online test }- \text { cheating } \\
\text { Based on participation }- \text { did not respond }\end{array}$ \\
\hline
\end{tabular}


Paper-Challenges in Emergency Remote Teaching Among Malaysian Public Elementary School...

\section{$5 \quad$ Findings}

Malaysian public elementary school teachers encountered various challenges in conducting ERT during the pandemic. There were six main themes that emerged in study. These themes emerged in four phases of instruction, namely planning instruction, developing instructional material, delivering instruction, and evaluating students' performance.

\section{$5.1 \quad$ Directing gateway}

In the phase of planning instruction, teachers' challenge was directing the gateway. The respondent teachers were not worried about the instruction as they were able to learn about remote teaching based on the available online resources. However, they faced another challenge which was the technical problem of helping students and parents to log into the designated platform. Some teachers shared their experiences:

'The instruction was not a problem, the biggest problem was that students did not know how to use those Apps and devices.' (Teacher 6)

'I kept receiving calls from parents and students and asked me 'Why can't I click this or that? Why had clicked but no reaction? What was their password?' (Teacher 8)

'I was annoyed. I had to teach them how to use computers or smartphones before I teach Malays.' (Teacher 4)

Some respondents reported that they had problems in guiding parents who had no digital skill. These teachers had to first teach parents before accessing their students. Some students were taken care of by older caregivers like grandparents, some parents were foreigners like Vietnamese, Thai or Indonesian, these situations caused some hassle in the beginning of emergency remote teaching. According to the respondents, as long as they could direct the gateway to parents and students, the instruction would become easy.

\subsection{Lack of knowledge and skill}

Some teachers who were not familiar with Microsoft PowerPoint and Google Slides encountered some setbacks at the point of departure, especially those teachers who were born before 1980. Unlike Science and Maths teachers, these teachers used to teach language subjects in traditional face-to-face classrooms without implementation of technology. The sudden shift of instructional format had forced them to master the knowledge and skills to alter the instructional material for digital use. These teachers untangled their problems by collaboration with co-workers, either in teachers' group chat or school in-house training. As some respondents reflexed:

'I had joined a few teachers' group chat. I was supported by teachers from all over Malaysia. I also called my colleague who was good at ICT to help me. (Teacher 2)

'My school provided in-house training during that time. I went back to school in May and managed to learn it within sessions of training.' (Teacher 3)

'I had to ask my secondary school children to teach me how to prepare presentation slides and Google Form..... I wasn't sure I was teaching or learning. It was a mess 
Paper-Challenges in Emergency Remote Teaching Among Malaysian Public Elementary School...

that I had to ask my children to stand by when conducting remote teaching' (Teacher 1)

Teachers had dreadful experience in converting paper-based instructional materials into digital based. However, they felt easier and effortless in later phases when they got familiar with the applications.

\subsection{Unable to meet students' need}

The respondents mentioned that they were not able to give immediate feedback and further explanation to students in ERT, especially the lower primary students who need immediate feedback and explanation to understand the instructional content. It was hard for teachers to do so in an online class. As one of the respondents shared his experience:

'The young students simply don't understand when I say 'this one' or 'that one'. They would keep asking which one I referred to. If I were in a face-to-face session, I could point to them immediately.' (Teacher 4)

Most respondents in the study agreed that some students need extra psychological support, for example a pat on their shoulder, a hand sign of good, a clap, etc to gain confidence and motivation to move on. Nonetheless, that was unachievable in an online class. Those students who needed psychological support did not participate actively in the class. According to the respondents, they were the 'special' group. Teachers found that it was difficult to access them in emergency remote teaching. As one of the teachers shared her thought:

'They were so shy that they did not respond in the online class. I know he is trying hard but I can't assist him online. I hope I can give him a pat to support him.' (Teacher 5)

In this study, the elementary school teachers encountered difficulties in meeting different students' needs, specifically students who were weak and problematic. As these students require special support and extra attention, a direct interaction is needed to provide encouragement to keep them motivated.

\subsection{Unable to engage students}

Teacher respondents felt frustrated as they can't gain control like how they did in the classroom during the school closure. They had difficulties in managing online class discipline. Some students were absent for the online class, some students created noise and chaos during the video conferencing session, but teachers were not able to do anything except kicking them out of the session. Some teachers shared their experience in delivering instruction online:

"I wasn't not sure if students were listening or staying in front of the screen because they switched off their camera due to poor internet connection. They also switched off their mic at all times.' (Teacher 1)

'Most of the time, I was talking to myself and no one answered my question. I was not sure if anyone was listening. I was frustrated.' (Teacher 3)

The respondent teachers claimed that they can't control what students did at home. Most of the students switched off camera and microphone, remained silent and did not 
Paper-Challenges in Emergency Remote Teaching Among Malaysian Public Elementary School...

respond to teachers' questions. Students seemed not interested and did not pay attention to what they were lecturing. For asynchronous class, teachers had to chase students to get the assigned homework done. Some respondent teachers expressed their feeling with sigh:

'As long as I get paid, just do whatever we can.' (Teacher 4)

\subsection{Lack of support from parents}

Some teachers in this study experienced an unpleasant moment when parents criticised and questioned about the instructional quality directly in front of the students during the video conferencing session. This made them feel embarrassed and uncomfortable as other students were watching. One of the respondents shared her experience:

'When I conducted a video-conferencing session, the parents sat beside the children and watched me. During lessons, the parents questioned me and said I teach wrongly. They argued with me in front of other students. It was so embarrassing. I was so stressed and worried about attending that class again.' (Teacher 5)

Based on the data collected in this study, most of the respondents felt stressed when the parents watched them in an online class. Even teachers could not see parents on the screen but they felt like being supervised.

Some teachers were criticised as lazy, not responsible and got paid without doing a job. According to these teachers, parents thought that the elementary school teachers only assigned homework without effective instruction, they had to bear the responsibility as tutor to ensure all tasks and assignments had been done correctly, yet teachers got salaried without a cut at the end. This situation made teachers feel that they were disrespected and not appreciated by parents. The respondents reported that the major factor contributing to their frustration and stress was that they didn't not get enough support from parents.

\subsection{Had no proper guideline}

Based on the data collected in this study, not all school teachers were required to evaluate students' performance in emergency remote teaching during pandemic. However, all the respondents agreed that there is a need to evaluate the students' performance again when everything goes back to normal because the evaluation during the pandemic was not reliable.

In ERT, teachers were not able to evaluate students' performance using observation and test because some students switched off their camera and mic during online class. This situation caused teachers to change their format of evaluation using other methods.

Some teachers are forced to evaluate students' performance by their attendance and participation. According to respondents, although it was not fair to some other students who can't participate in the virtual classroom synchronously or asynchronously, they had no other options. Some respondents shared his experience in evaluating students' performance. 
'I was so angry that no one answered my question and no one bothered what I was doing. I graded them based on the attendance. Those who logged in got better grades, those who were absent got band 2.' (Teacher 10)

'Some students had financial problems. They did not have enough devices at home. All siblings had to share. They had no other options other than absence. I can't grade them because of this, right? It's unfair.' (Teacher 6)

According to the respondents, it was absolutely a reasonable excuse to say that internet connection was bad. They had to accept the reason and surrender to evaluating students' performance based on observation in an online lesson.

The respondents in this study thought that the evaluation on students' performance during pandemic was unreliable, especially the evaluation based on students' homework or project. During the lockdown period, parents who stayed home became the 'tutor' to the students. Students referred to parents when they came across problems in completing homework or projects. Most of the homework was done by others but not students themselves. For homework in Google Form, students only did it randomly for the sake of completing. Some teachers also tried to hold online tests but it did not work well as students were caught cheating. Some teachers shared his experience in evaluating students' performance through their homework during pandemic:

'I tried to give an online test during that period. I forced the student to switch on their camera and only prepared 6 questions. Everything was looking good. But suddenly I received a message. That was from one of the students. He sent the message wrongly. You know what, he was actually cheating with his friends through WhatsApp. Unfortunately, he sent the message to the wrong group chat. That's why I found out.' (Teacher 5)

Based on the data analysis, the elementary school teachers faced some problems in evaluating students' performance when conducting emergency remote teaching. They had no clear ideas on how to evaluate students' performance fairly. They tried to adopt the evaluation system which was designed for face-to-face learning in emergency remote teaching but they encountered huge barriers in accessing students' performance. Neither students' performance nor quality of instruction, they were not able to have an unambiguous guideline to assess its efficiency and effectiveness.

\section{Discussion}

This section discussed all the six emerged main themes of public elementary school teachers' challenges in conducting emergency remote teaching in Malaysia.

\subsection{Directing gateway}

Emergency remote teaching is distinct from online learning. In online learning, the development and resources are supported by institutions whereas emergency remote teaching is fully self-supported [16]. Teachers or educators had to handle the whole emergency remote learning environment by themselves from technical aspects like ac- 
cessibility platforms to internal aspects like materials and content. A research on a review of teachers' digital skill, Malaysia stood out as having the fourth-highest proportion of digital natives in the world, despite ranking much lower globally in ICT development [15], stepping into any classroom in the country today is almost the same as stepping in to any classroom 20 years ago, teachers were ill-prepared to teach with technology [38], teachers in Malaysia had encountered enormous setback in helping parents and students in accessing to the remote learning system as they themselves were not ready for the remote teaching and the digitalization in education ecology. As teachers, they had no problem carrying out instruction obligations but they were not the expert with excellent information and communication technology (ICT) backgrounds. The process of planning instruction during the pandemic became a burden to these elementary school teachers as they had to act as technician or ICT expert to assist parents and students to access the education platform.

\subsection{Lack of knowledge and skill}

The respondent teachers mentioned that they did spend plenty of time in developing instruction materials in the beginning. The result was aligned to many studies from other countries, where teachers encountered problems like lack of time for preparation, lack of skill and knowledge, lack of ICT competency [12, 18, 22, 32] in conducting emergency remote teaching. However, the time spent mostly because they had not mastered the skill yet or they were not used to the new format of instruction. As they progress in the later phase of remote teaching, developing digital instructional material has become a norm within their job. The migration of the working environment in fact has accelerated teachers' digital skill. By the time of writing, almost all elementary school teachers had mastered a certain level of digital literacy. In other words, emergency remote teaching had worked as a catalyst to educational technology instead of a disaster to all teachers.

\subsection{Unable to meet students' need}

The biggest challenges in emergency remote teaching were in the phase of delivering instruction. During pandemic, elementary school teachers encountered difficulties as it was hard to maintain an affectionate interaction between educators and learners. Teachers found that it was difficult to meet different students' needs, unable to provide immediate feedback [18], especially students who need more attention. The result was aligned to the study by [41] where teachers faced challenges in monitoring students in an online environment.

\subsection{Unable to engage students}

Due to the inexistence of instructional design for emergency remote teaching, inexperienced teachers tended to move all instructional materials online and gave instruction as they did previously in the classroom. They adopted teacher-centred pedagogy, gave direct online lecturing and thought the difference between remote teaching and 
face-to-face teaching was just format. This was the main cause of failure in engaging students. According to [16], emergency remote teaching should be focused on ensuring students learn in a flexible, inclusive and student-centred learning environment, including accessing all learning materials, learn activities, and assignments [41]. A studentcentred educational approach is the main factor in learners' satisfaction and for the successful integration of ICT instruments when using online technologies $[10,25,28,35$, 40]. The type of instructional pedagogy which was adopted by educators was crucial in emergency remote teaching in engaging students' participation. Due to the short time of preparation in emergency remote teaching, educators were not able to develop effective materials as well as class assessment or formative assessment that suit every student's need. On the other hand, they adopted instructional modules which were designed for learners' standard age instead of students' learning pace or ability. Students with faster pace could explore better if the teacher works as facilitator, students with slower pace would feel isolated as they cannot catch up what was happening. Students' isolation feeling may impact their confidence level in remote learning and interfere with their sense of belonging [35]. Aligning to a research of [41] in remote large class-size, meeting students' need at both ends of the learning ability spectrum was impossible.

\subsection{Lack of parents' support}

Some Malaysian elementary school teachers in this study experienced frustration and had low self-esteem when they were challenged by parents in emergency remote teaching. This was because teachers had not received any professional training yet before conducting emergency remote teaching. They were not fully prepared or maybe not fit yet for remote teaching. The parents' skeptical attitude towards emergency remote teaching had become a barrier to effective communication between teachers and parents $[4,11,41]$. Some parents had doubted the effectiveness and necessity of remote teaching, some parents experienced personal stress during the lockdown period, and the worst thing was that not all teachers were professionally trained to handle communication or dealing with conflict with adults outside the learning environment. Be it personal or career, teachers did have their own stresses within the context of pandemic. In circumstances, teachers faced huge challenges in delivering instruction especially when parents were watching them or not supporting them.

\subsection{Had no proper guideline}

In this study, the respondent teachers claimed that they had no proper guideline to evaluate students' performance. The findings of the study aligned to the study of [3] where teachers were unable to judge students' performance and attitude as the condition did not reflect actual circumstance. As in a study of [16] where the evaluation should be more focused on the context, input and process elements that product (learning). We should concentrate more on how to produce an effective and efficient remote teaching framework to counter the crisis of education instead of evaluating how much students have learnt. Perhaps, the emergency remote teaching is an opportunity for all educators 
Paper-Challenges in Emergency Remote Teaching Among Malaysian Public Elementary School...

to evaluate the current instructional concept and how it should be done to meet the new generation's needs.

\section{Conclusion}

Findings highlight the challenges that teachers have faced when conducting emergency remote teaching during pandemic. By listening to teachers' voices, we could gain information about how teachers can be supported to benefit learners and the communities. The emergency remote teaching has now become official remote teaching and learning for all learners and educators. The COVID-19 pandemic definitely will not be the last major infectious disease that puts learners at risk. The integration of flexibility, resilience, effective collaboration and communication from all stakeholders to support the most vulnerable learners is important.

\section{$8 \quad$ Limitation and future study}

This study adopted a cross-sectional design which is merely a snapshot of teachers' experience during the 1st and 2nd phase (Mar-July 2020 and Nov-Dec 2020) of emergency remote teaching in Malaysia. As the emergency remote teaching transformed to remote teaching during the pandemic, the experience and perception of elementary school teachers would change over time. Besides, the current study drew samples from the state of Johor, the study in remaining parts of Malaysia may vary in experience and perception. The sample were language teachers, challenges and perceptions of teachers who teach other subjects like Science and Mathematics might be different. Lastly, this study only focused on national elementary school teachers' challenges faced and perception in private schools or secondary schools are likely to be different.

\section{Acknowledgement}

The authors would like to thank Mohamo Resources and Universiti Teknologi Malaysia for their support in making this project possible. This work was supported by the Contract Grant Scheme (R.J130000.7653.4C436) initiated by Mohamo Resources.

\section{Reference}

[1] Adarkwah, M.A., "I'm Not Against Online Teaching, But What About Us?": ICT in Ghana Post Covid-19, Education and Information Technologies, 26 (2021) 1665-1685, https://doi.org/10.1007/s10639-020-10331-z

[2] Alhumaid, K., Ali S., Waheed A., Zahid E., Habes M., COVID-19 \& Elearning: Perceptions \& Attitudes of Teachers Towards E-Learning Acceptance in The Developing Countries, Multicultural Education, 6 (2020), http://dx.doi.org/10.5281/zenodo.4060121

[3] Aliyyah, R.R., Rachmadtullah R., Samsudin A., Syaodih E., Nurtanto M., Tambunan A.R.S., The Perceptions of Primary School Teachers of Online Learning During The 
Paper-Challenges in Emergency Remote Teaching Among Malaysian Public Elementary School...

COVID-19 Pandemic Period: A Case Study in Indonesia, Journal of Ethnic and Cultural Studies, 7 (2020) 90-109, https://doi.org/10.29333/ejecs/388

[4] Asbury, K., Kim L., "Lazy, Lazy Teachers": Teachers' Perceptions of How Their Profession Is Valued By Society, Policymakers, and The Media During COVID-19, (2020), DOI: https://doi.org/10.31234/osf.io/65k8q

[5] Bartley, S.J., Golek J.H., Evaluating the Cost Effectiveness of Online and Face-To-Face Instruction, Journal of Educational Technology \& Society, 7 (2004) 167-175.

[6] Braun, V., Clarke V., Thematic Analysis, (2012), https://doi.org/10.1037/13620-004

[7] Brophy, J.E., Teaching, International Academy of Education and The International Bureau of Education (1999)

[8] Carliner, S., An Overview of Online Learning, (2004)

[9] Creswell, J.W., Educational Research: Planning, Conducting, and Evaluating Quantitative, Prentice Hall Upper Saddle River, NJ, (2002)

[10] Englund, C., Olofsson A.D., Price L., Teaching with Technology in Higher Education: Understanding Conceptual Change And Development in Practice, Higher Education Research \& Development, 36 (2017) 73-87, https://doi.org/10.1080/07294360.2016.1171300

[11] Fauzi, I., Khusuma I.H.S., Teachers' Elementary School in Online Learning of COVID-19 Pandemic Conditions, Jurnal Iqra': Kajian Ilmu Pendidikan, 5 (2020) 58-70, https://doi.org/ $\underline{10.25217 / \text { ji.v5i1.914 }}$

[12] Ferri, F., Grifoni P., Guzzo T., Online Learning and Emergency Remote Teaching: Opportunities and Challenges in Emergency Situations, Societies, 10 (2020) 86, https://doi.org/ $10.3390 /$ soc 10040086

[13] Giovannella, C., Measuring The Effect of The Covid-19 Pandemic on The Italian Learning Ecosystems at The Steady State: A School Teachers' Perspective, (2020).

[14] Guangul, F.M., Suhail A.H., Khalit M.I., Khidhir B.A., Challenges of Remote Assessment in Higher Education in The Context Of COVID-19: A Case Study of Middle East College, Educational Assessment, Evaluation and Accountability, 32 (2020) 519-535, https://doi.org/ $\underline{10.1007 / \mathrm{s} 11092-020-09340-\mathrm{W}}$

[15] Had, M.Z.C., Rashid R.A., A Review of Digital Skills of Malaysian English Language Teachers, International Journal of Emerging Technologies in Learning, 14 (2019), https://doi.org/10.3991/ijet.v14i02.8732

[16] Hodges, C., Moore S., Lockee B., Trust T., Bond A., The Difference between Emergency Remote Teaching and Online Learning, Educause Review, 27 (2020) 1-12, https://Er.Educause.Edu/Articles/2020/3/The-Difference-Between-Emergency-Remote-Tea,ching-AndOnline-Learning

[17] Husain, B., Idi Y.N., Basri M., Teachers' Perceptions on Adopting E-Learning during COVID-19 Outbreaks; Advantages, Disadvantages, Suggestions, Jurnal Tarbiyah, 27 (2021), https://doi.org/10.30829/tar.v27i2.738

[18] Joshi, A., Vinay M., Bhaskar P., Impact of Coronavirus Pandemic on The Indian Education Sector: Perspectives of Teachers on Online Teaching and Assessments, Interactive Technology and Smart Education, (2020), https://doi.org/10.1108/ITSE-06-2020-0087

[19] Karakaya, F., Adigüzel M., Üçüncü G., Çimen O., Yilmaz M., Teachers' Views Towards The Effects of Covid-19 Pandemic in The Education Process in Turkey, Participatory Educational Research, 8 (2020), https://doi.org/10.17275/per.21.27.8.2

[20] Karakaya, F., Selçuk A., Cimen O., Yilmaz M., Investigation of The Views of Biology Teachers on Distance Education during The COVID-19 Pandemic, Journal of Education in Science Environment and Health, 6 (2020) 246-258, https://doi.org/10.21891/jeseh.792984 
Paper-Challenges in Emergency Remote Teaching Among Malaysian Public Elementary School...

[21] Klapproth, F., Federkeil L., Heinschke F., Jungmann T., Teachers' Experiences of Stress and Their Coping Strategies During COVID-19 Induced Distance Teaching, Journal of Pedagogical Research, 4 (2020) 444-452, https://doi.org/10.33902/JPR.2020062805

[22] Korkmaz, G., Toraman Ç., Are We Ready For The Post-Covid-19 Educational Practice? An Investigation into What Educators Think as to Online Learning, International Journal of Technology in Education and Science, 4 (2020) 293-309 https://doi.org/10.46328/ ijtes.v4i4.110

[23] Malekolkalami, M., The Perception Of Iranian Teachers on Online Teaching Using Digital Carrier during The COVID-19 Pandemic, International Journal of Digital Content Management, 1 (2020) 109-126.

[24] Mohalik, P., Sahoo S., Accessibility, Competency and Perception of School Teachers Towards Online Teaching in The Midst of COVID-19 Pandemic, (2021), https://doi.org/ $\underline{10.2139 / \text { ssrn.3791919 }}$

[25] Mun, S., Abdullah A., Mokhtar M., Ali D., Jumaat N., Ashari Z., Samah N., Rahman K., Active Learning Using Digital Smart Board To Enhance Primary School Students' Learning, (2019), https://www.learntechlib.org/P/216524/

[26] Nambiar, D., The Impact of Online Learning During COVID-19: Students' and Teachers' Perspective, The International Journal of Indian Psychology, 8 (2020) 783-793, https://doi.org/10.25215/0802.094

[27] Oducado, R.M., Rabacal J., Moralista R., Tamdang K., Perceived Stress Due to COVID-19 Pandemic among Employed Professional Teachers, International Journal of Educational Research And Innovation,(15), (2021) 305-316, https://doi.org/10.46661/ijeri.5284

[28] Omar, M., Ali D., Mokhtar M., Zaid N., Jambari H., Ibrahim N., Effects of Mobile Augmented Reality (MAR) Towards Students' Visualization Skills when Learning Orthographic Projection, International Journal of Emerging Technologies in Learning (IJET), 14 (2019) 106-119, https://www.learntechlib.org/P/217115/

[29] Oyedotun, T.D., Sudden Change of Pedagogy in Education Driven by COVID-19: Perspectives and Evaluation from a Developing Country, Research in Globalization, 2 (2020) 100029, https://doi.org/10.1016/j.resglo.2020.100029

[30] Panisoara, I.O., Lazar I., Panisoara G., Chirca R., Ursu A.S., Motivation and Continuance Intention Towards Online Instruction Among Teachers during The COVID-19 Pandemic: The Mediating Effect of Burnout and Technostress, International Journal of Environmental Research and Public Health, 17 (2020) 8002, https://doi.org/10.3390/ijerph17218002

[31] Portillo, J., Garay U., Tejada E., Bilbao N., Self-Perception of The Digital Competence of Educators during The COVID-19 Pandemic: A Cross-Analysis of Different Educational Stages, Sustainability, 12 (2020) 10128, https://doi.org/10.3390/su122310128

[32] Sahoo, S., E-Readiness and Perception Of Student Teachers' Towards Online Learning in The Midst Of COVID-19 Pandemic, Available At SSRN 3666914, (2020) http://dx.doi. org/10.2139/ssrn.3666914

[33] Sewell, K., Newman S., What Is Education, Education Studies: An Issue Based Approach, (2014).

[34] Sokal, L., Trudel L.E., Babb J., Canadian Teachers' Attitudes Toward Change, Efficacy, and Burnout During The COVID-19 Pandemic, International Journal of Educational Research Open, 1 (2020) 100016, https://doi.org/10.1016/j.ijedro.2020.100016

[35] Tartavulea, C.V., Albu C.N., Albu N., Dieaconescu R.I., Petre S., Online Teaching Practices and The Effectiveness of The Educational Process in The Wake of The COVID-19 Pandemic, Amfiteatru Economic, 22 (2020) 920-936 https://doi.org/10.24818/EA/2020/55/920 
Paper-Challenges in Emergency Remote Teaching Among Malaysian Public Elementary School...

[36] Tilea, M., Duță O.-A., Ólafsdóttir S., A Romanian and Icelandic Language Student's Profile from The Perspective of Education for Democratic Citizenship, Social Sciences and Education Research Review, Volume 7, Issue 1, 2020, (2020) 129.

[37] Van Der Spoel, I., Noroozi O., Schuurink E., Van Ginkel S., Teachers' Online Teaching Expectations and Experiences During The Covid19-Pandemic In The Netherlands, European Journal of Teacher Education, 43 (2020) 623-638, https://doi.org/10.1080/02619768. 2020.1821185

[38] Whalen, J., Should Teachers Be Trained in Emergency Remote Teaching? Lessons Learned from The COVID-19 Pandemic, Journal of Technology and Teacher Education, 28 (2020) 189-199, https://www.learntechlib.Org/Primary/P/215995/

[39] Worley, W.L., Tesdell L.S., Instructor Time and Effort in Online and Face-To-Face Teaching: Lessons Learned, IEEE Transactions on Professional Communication, 52 (2009) 13815, https://doi.org/10.1109/TPC.2009.2017990

[40] Zaid, N.M., Yaacob F., Shukor N.A., Said M.M., Musta'amal A., Rahmatina D., Integration of Peer Instruction in Online Social Network to Enhance Higher Order Thinking Skills, (2018), https://doi.org/10.3991/ijim.v12i8.9672

[41] Zhang, T., Learning from The Emergency Remote Teaching-Learning in China when Primary and Secondary Schools were Disrupted by COVID-19 Pandemic, Research Square, (2020), https://doi.org/10.21203/rs.3.rs-40889/v1

\section{Authors}

Yong Keow Lee is a master student of Educational Technology in School of Education, Faculty of Social Science and Humanities, Universiti Teknologi Malaysia, Malaysia. She received the degree of Bachelor of Art (Honors) in Chinese Studies (2003) from Universiti Malaya (UM). She is an enthusiast of marathon and ultramarathon in Malaysia. She was the champion of Malaysia Sundown Marathon (2017), Singapore Bedok Reservoir Ultramarathon (2017) and qualified for the world's oldest Western State 100-miles Endurance run in 2018 (email: keowlee@graduate.utm.my).

Norasykin Mohd Zaid is a senior lecturer at the School of Education, Faculty of Social Sciences and Humanities, Universiti Teknologi Malaysia. She received the degree of Bachelor of Science (Honors) in Computer Science (2000) and the Master degree (Educational Technology) (2006) from Universiti Teknologi Malaysia (UTM), Malaysia and the Ph.D. degree from University of Wollongong (UoW), Australia in 2013. She is the Program Coordinator of the Educational Technology Program for Postgraduate Studies since 2018. Her research interests include online education and training, information systems and new media in teaching and learning.

Nur Husna Abd Wahid is a senior lecturer in the department of Technical and Engineering Education UTM where she has been a faculty member since 2006. She completed her Ph.D. at Pennsylvania State University in Workforce Education \& Development in 2016. Her research interests are in agricultural education, technical and vocational and training, teacher preparation, and global teacher competencies. Recently her research explores how diversity in ethnicity, culture, language, and socioeconomic class impact teaching preparedness in technical and vocational education. Dr. Nur Husna international/global learning experience includes her involvement as the Global 
Teach Agriculture Initiative Visiting Scholar (2013-2016) at the Department of Agricultural Economics, Sociology, and Education, Penn State.

Zakiah Mohamad Ashari is currently serving as Senior Lecturer since 2015 at the School of Education, Faculty of Sciences Social and Humanities, Universiti Teknologi Malaysia. She holds a degree in Preschool Education from Universiti Universiti Sains Malaysia and Ph.D. degree in Educational Psychology from Universiti Teknologi Malaysia. Zakiah has conducted a study on teaching and learning in preschool education, early mathematical learning, child development, module development as well as using ICT as medium in learning.

Nornazira Suhairom is a senior lecturer and researcher at the School of Education, Faculty of Social Sciences and Humanities, Universiti Teknologi Malaysia. She has been working with UTM since 2006. She received the degree of Bachelor of Science (Food Studies) in 2006 and the Master of Science (Technical and Vocational Education) (2012) from Universiti Putra Malaysia (UPM) and the Ph.D. degree (Technical and Vocational Education) from Universiti Teknologi Malaysia in 2016. Her research interests include work-based learning, information-seeking behavior and project-based implementation in teaching and learning.

Mohd Nihra Haruzuan Mohd Said is an Associate Professor at School of Education, Faculty of Social Sciences and Humanities, Universiti Teknologi Malaysia. He is currently the Information Technology Manager at the Centre of Academic Leadership Universiti Teknologi Malaysia. His interests lie at the intersection of Educational Technology, e-Learning, Online Learning, Information and Communications Technologies in Education and Academic Leadership. He has 14-year experience with the field of education and technology in the United Kingdom, New Zealand, Australia and Singapore. Contact information is School of Education, Universiti Teknologi Malaysia, 81310 Johor, Malaysia. For more information, please visit the following webpage: https://people.utm.my/nihra (email: nihra@utm.my).

Article submitted 2021-10-01. Resubmitted 2021-10-29. Final acceptance 2021-10-30. Final version published as submitted by the authors. 